\title{
Deli Dumrul Mitosu Bağlamında Türk-İslam Özneliğinin Psiko-Mitolojik Çözümlenmesi ${ }^{*}$
}

\section{Efe Baştürk ${ }^{* *}$}

öz

Her toplum, kendi kolektif örgütlenmesine uygun biçimde bir anlam dünyası kurgular. Mitos, bu anlam dünyasının toplumu ve benliği kurması üzerine tasarlanmış bir anlatıdır. Psiko-mitoloji ise, kolektif kültürün gelişimini ve etkisini, benliğin psişik dönüşümleri üzerinden tartışan bir yorumlama biçimidir. Türklerin İslamiyet'e geçişini konu alan Deli Dumrul efsanesi, Şamanist inancın içinde yetişen kahramanın, kendi ölümlülüğünü idrak etmesi karşısında girdiği travmayı konu alır. Bu travmanın kökeninde yatan etmen, Türklüğün doğacıl ve anahanlı örgütlenme psikolojisinin, İslamiyet' in normatif dizgesiyle karşılaşma anında sarsıntı geçirmesidir. Deli Dumrul efsanesi, Türklerin İslamiyet ile beraber edindikleri öznellik biçimine dahil olma sürecindeki deneyimleri içermesinden dolayı, psiko-mitolojinin sorunsal nesnesi olarak ele alınabilir.

\section{Anahtar Kelimeler}

Türklük, anahanlık, islamiyet, psiko-mitoloji, söylen (mit), Deli Dumrul.

Geliş Tarihi: 23 Aralık 2016 - Kabul Tarihi: 25 Nisan 2017

$\mathrm{Bu}$ makaleyi şu şekilde kaynak gösterebilirsiniz:

Baştürk, Efe (2019). “Deli Dumrul Mitosu Bağlamında Türk-İslam Özneliğinin Psiko-Mitolojik Çözümlenmesi”. bilig - Türk Dünyası Sosyal Bilimler Dergisi 89: 29-54

** Doç. Dr., Recep Tayyip Erdoğan Üniversitesi, İIBF, Siyaset Bilimi ve Kamu Yönetimi Bölümü - Rize/ Türkiye

ORCID ID: https://orcid.org/0000-0001-7117-0734

efe.basturk@erdogan.edu.tr 


\section{Giriş: Psiko-Mitolojik Bir Okuma Denemesinin Hipotezi Üzerine}

Toplumların kültürel gelişimi ile uyruklarının veril kültürel norm evreni tarafından biçimlendirilmesi olgusu, yalnızca toplumsal-tarihsel bağlamda ele alınmamalıdır. Bir topluluğun kendisini inşa etmesi, sadece fiziksel sınırlar imal ederek belirli bir iç-dış (biz-onlar) ayrımı üzerine temellenmiş politik-toplumsal örgütlenmeden ibaret değildir (Noland 2010: 96-97). Topluluk, aynı zamanda manevi bir birlikteliktir; uyruklarının zihinlerinde, ruhlarında ve fakat çoğu zaman onların düşünsel evrenlerinin anlamlandıramadığı noktalar olarak sayılabilecek bilinçdışı izleklerde temsil edilen ve yeniden üretilen tinsel bir simgedir. Bu anlamda topluluk, insanların bir araya gelerek oluşturdukları somut bir-aradalıklarından bir fazla anlam içeren ve onların maddi birliklerine tinsel bir anlam katarak onları ezeli ve ebedi bağlamda birleştiren bilinçdışısal bir örgütlenmedir (Obeyesekere 2011: 18). Toplulukların örgütlenme biçimleri ile insanların belli anlam sistemleri dahilinde bir topluluk-olarak var olma veya insanın neden ve nasıl bir topluluksal örgütlenme içerisinde özne olarak addedilebilir olduğunu çözümleme yöntemi olarak psiko-mitoloji, insanın bilinçsel gelişimi ile topluluğun örgütlenmesi arasındaki bağın çözümlenmesi üzerine odaklanan bir yorumlama denemesidir.

Mitlerin hem tarihsellik anlamında eskiliği, hem de güncelliğini halen koruyabilmesi anlamında yeniliği, tam da psiko-mitolojinin önermesi ile uygunluk taşıyacak bir biçimde karşımıza çıkmaktadır. Niles' in söylediği gibi, insanın "bir öykü yoluyla" var olan bir canlı oluşu (Niles 1999: 1), bu öykülemenin arkaik kuruculuğunu süreklileştirir. İnsanın öykü yoluyla evrende yolunu bulması, eski çağlara dek izi sürülebilecek arkaik bir mirastır ve toplumlar, bu mirası kendi özgüllüklerine göre uyarlamayı başarmışlardır (Leeming 1990). Söylen (mitos/mit), toplumların bir arada olmalarına ilişkin nedensellikleri, gereksinmeleri ve arzuları nümayiş eden görüngülerdir; bu nedenle verili bir toplumsal örgütlenmeyi mitsel okuma denemesi, topluluğun mitsel sunumunun görüngübilimsel incelenmesini zaruri kılmaktadır. Bu zaruriyetin temelinde yatan unsur, söylen adı verilen fenomenin toplumun tarihsel gelişiminden bağımsız olmaması, tersine, toplumun aldığı biçimlenme ile uygunluk taşıyor olmasıdır (Johnson 1992: 19). 
Topluluğun kendi varoluşunu mitsel -ya da mitos üzerinden- deneyimlemesi (Campbell 2006), yalnızca söylencesel bir analizi değil, fakat aynı zamanda bilincin bilinçdışı ile ilişkilendiği psişik süreci de içermelidir. Bunun nedeni, topluluğun söylence üzerinden okunmasının, bu söylencenin işaret ettiği simge ve sembolik dizgelerin psişik temsillerin de değerlendirmeye alınmasını gerektirmesidir. Başka bir deyişle, mitoslar, ben ve [tinsel] topluluk arasındaki bir araya gelişin sembolik kurgusu olarak geçmişi değil, tersine, şimdi' yi ifade eder ve benliğin tinsellik dolayımıyla inşasını içerir. Bu nedenle mitosların konusu, özneleşme sürecine dâhil olan insanın öyküsü olarak, tarihe dâhil oluştur. Bu dâhil olma süreci, insanın anlam kipinden uzakta bulunduğu ilksel varoluşun ötesine geçerek kendisine tinsel bir anlamın katıldığı kültürel dizgeye katılması anlamına gelir. Nihayetinde mitos, insanın ilksel bilinç-öncesi varoluşu ile kültürel özneleşmesi arasındaki travmatik geçişi sembolize eden anlatılar olarak karakterize edilebilir.

Bu çalışmanın amacı, ilksel varoluş ile kültürel özneleşme arasındaki travmatik deneyimi Türk mitolojisinin önemli bir uğrağı sayılabilecek olan ve İslamiyet ile karşılaşma anını konu alan Deli Dumrul adlı söylence üzerinden psiko-mitolojik bağlamda incelemektir. Söylencenin ana konusu, ölümün temsil edildiği Azrail ile karşılaşma anının yaratmış olduğu travmadır. Eski Türk mitolojisinde ölümün temsil edilme biçimlerine ilişkin iki tür yargıdan bahsetmek mümkündür. Bunların ilki, eski Türk toplum inancını çoklu-tanrı inancı biçiminde formüle eden bir anlayıştır. İkincisi ise, başlangıçtan itibaren Türklerin inanç sistematiğinde tek-tanrı inancının bulunduğunu öne süren yaklaşımlardır (Günay ve Güngör 2015: 23-28). Bu yaklaşımların her biri eski Türk inancını kendi özgül bağlamı içerisinde değerlendirmeye almış olsa da bu çalışmada disiplinler arası bir teorik güzergahın önerilebilmesi adına biraz evvel yukarıda zikredilen birinci yaklaşım takip edilecektir. Bununla amaçlanan, ilgili yaklaşımın muhtevasında barındırmış olduğu çok yönlü okuma imkânına el veriyor olmasıdır. Buna göre, söylencenin çözümlenmesinde merkezi bir rol oynayan travmatik bağlam,çoklu tanrı inancı sistematiği içerisinde tanıtlanmış bilinç-öncesi varoluşun, tek Tanrı gerçeği ile karşılaşması neticesinde ilksel varoluşu ve buna ilişkin simgesel kodlar ile mesafelenme zorunluluğu arasındaki travma olarak özetlenebilir. Bu travmatik deneyim Deli Dumrul'un şahsında söylencesel bir kurgu şeklinde oluşturulmuş olsa da, esasında Türklüğün İslamiyet'e ait normatif-kültürel Yasa tarafindan soğrulmasını içerecek çapta kolektif-tarihsel bir inşayı gündeme getirmektedir. 
Nitekim, çoklu tanrı inancı karşısında Azrail'de kavranan tek Tanrı olgusu ile karşılaşmanın benlik, toplum ve dünya tasavvurları üzerindeki radikal bağlamda dönüştürücü etkisi göz önünde bulundurulduğunda, bu söylencenin Türk-İslam özneliğinin kuruluş an'ı olarak ele alınması makul sayılabilir. Türk inanç mitolojisinde Azrail, dışarıda bırakılan ve bu bağlamda özne ile mesafelenmiş bir biçimde kurgulanan dişsallık iken (Duymaz 2008: 11-13), tek-tanrı inancına dâhil olunma nedeniyle özneliği kuran kültürel-sembolik yapıya içkinleşerek özne ile mesafesizleşen bir varlığa tekabül etmektedir. Zira bu kırılma anı, Türklere özgü kimi kolektif örgütlenme ve tekil varoluşsal dizgelerde aşınma ve aşılma yaratmıştır. Şamanist [animist] tahayyülün yerine ayrımlaşmış dünyaya dışarıdan hükmeden bir, tek ve mutlak Tanrı fikrinin geçmesi veya yine Şamanist dizge ile uyumlu sayılabilecek anahanlı (anacil/ dişil) örgütlenmeden patriarkal-Babahanlı örgütlenmeye sıçrayış, benlik ve topluluğun tinsel varoluşu bağlamında kırılma meydana getirmiştir.

\section{Psiko-Mitoloji Bağlamında Benlik ve Topluluğun Varoluşsal Deneyimi}

Psiko-mitoloji, benliğin topluluk içerisindeki özneleşme süreçlerini söylencelerde yer alan anlatılar üzerinden ele almayı deneyen bir yorumlama denemesi olarak psikanalizin alt başlıklarından bir tanesidir. Dolayısıyla, psiko-mitolojinin çabası, söylencelerde yer alan anlatılarda psikanalize ilişkin çıkarsamalarda bulunabilmek için metin çözümlemesi yapmaktır. Bu çalışmada da, psiko-mitolojik bir çözümlemenin olanaklarını tartışabilmek adına, psiko-mitolojinin psikanalizdeki belli başlı tartışmaları nasıl ele aldığına ve daha da önemlisi bu tartışmaları kendi kuramsal bağlamı içerisinde nasıl konumlandırdığına değinmek icap etmektedir.

Başta da ifade ettiğimiz üzere psiko-mitoloji, söylencelerde yer alan özneleşme süreçlerini ele alan efsanevi anlatılar olarak, topluluğun evrendeki konumuna ilişkin ontolojik bir bakış açısı sunmayı amaçlar. Bu bakış açısı, temelde, varlığın -bu ister topluluk olsun ister birey olsun fark etmeyecektir- konumunu anlamaya ve bu konumun nedensel parametrelerini keşfetmek üzere tasarlanmış bir kavrama çabasından doğar (Strauss 2013: 50). Strauss'un ilkel zihinle özdeşleştirdiği mit, topluluksal varlığın kendini kavrama çabasının bir ürünü olarak karşımıza çıkar. Bu içe-dönüşlü (reflexive) bakış açısı, varlığın kendini anlama gayreti olarak anlaşıldığında, mitsel anlatının en temelde dinsel bir adlandırma edimi olduğu daha rahat görülecektir. Çünkü dinsel kavrayış, Durkheim'cı ifadeyle, topluluğun kendisine dışarıdan bakması (Durkheim 
2011: 47) olarak, varoluşun bir tarafta maddi, diğer tarafta ise tinsel olmak üzere ikiye ayrılarak birbirine referansla kurulmasının temsilidir. Mitlerde ele alınan şey, tam da bu çifte bölünmüşlügün izlenebilir şekilde sunulmasıdır. Mitolojinin kahraman-merkezli failleştirme anlatısının (Rank 2016) temelinde yatan şey, hikâyenin merkezinde olan şahsın (birey/topluluk) kendisinin bilincine varabilme, yani kendiliğin fenomenolojik kavranışına ulaşma serüvenidir. Bu nedenle mitlerin konusu, kahraman anlatısı üzerinden, topluluğun öznel fenomenal bilincine ulaşma biçimleri ve dönüşümleridir.

Mitler bu nedenle psikanaliz ile yakından ilgilidir. Nasıl ki psikanaliz, insanın doğal ve kültürel varoluşu arasındaki gerilimi bilinçdışı üzerinden çözümleyerek (Zupancic 2011: 9) kendilik çözümlemesi geliştiriyorsa, mitoloji de, benzer bir çözümleme yoluyla topluluğun bilinçdışını bir anlatı üzerinden sunmaya çalışır. Bu nedenle mitlerde en ufak bir detayın dahi çok büyük önemi vardır; çünkü mit, sembolizasyon süreci yoğunlaştırılmış bir anlatı olarak içerik çözümlemesinden ziyade görüngübilim eleştirisidir (Saydam 2011: 9). Diğer bir deyişle mitlerde şeylerin nedensel belirlenimleri değil, bunların temsil ve gösterimleri ön plandadır. Dolayısıyla mitolojinin psikanaliz ile oldukça benzerlik taşıdığı söylenebilir; çünkü her ikisinde de amaç, varoluşun fenomenal bilincine bilinçdışısal süreçler ve temsiller aracılı̆̆ı ile ulaşmaktır. Psikanaliz için insanın davranışları, jest ve mimikleri, vb. görüngüleri bu bilinçdışı sürecin temel izleği iken, mitolojide de anlatımın sembolize edildiği ve hikâye kahramanının dönüşümünü izleyebileceğimiz simgesel biçimleri bu bilinçdışı sürecin ana çizgisini oluşturur. Yine her ikisi de, varoluşu ne bir tamlık (bütünlük) düzeyinde ne de sona ermişlik bağlamında ele alır; hem psikanaliz hem de mitoloji, varlığın kendilik (ego) yanılsamasından nasıl uzaklaştığını ortaya koyma amacındadır. Psikanaliz, bunu, Freud'dan beri kültürel dinamiklerin merkezde olduğu bir biçimde saptama uğraşındadır. Psikanalizin temel varsayımı, insanın bilinç düzeyinde saf bir kendilik kontrolü geliştiremediği ve onun itkilerini ve yönelimlerini düzenleyen gizil bir mekanizma olarak bilinçdışının var olduğu iddiası üzerine temellenir (Voloşinov 2016: 12-22).

Bilinçdışı, kendiliğin tek başına varlık-olma haline ulaşamayacağının bir göstergesidir. Kendilik kurulumunun ve kendilik bilincinin ancak dışarıdan bakış yoluyla deneyimlenebilir oluşu, kendilik çözümlenmesi için bilinçdışının analizini gerektirir. Bilinçdışı analizi, öncelikle, varlığın kendinde eksiltilmiş 
olduğu varsayımı ile hareket eder ve kendilik bilincine dışarıdan - daha doğrusu açığa çıkmamış düzlemlerden - müdahalede bulunan izleklerin eleştirisini yapmaya uğraşır. Bilinçdışı, bu bakımdan, kendiliğin konumuna ilişkin koordinatları veren bir harita gibidir; davranışların, düşüncelerin, yönelimlerin, kısaca kendiliğin dünyada konumlandırılışının anahtarı bilinçdışısal izleğin kendisindedir.

Mitlerdeki kurgu, tam da bu bağlamda, kolektif bilinçdışının izlenmesi ve çözümlenmesi anlamında bir tür kendilik kavrayışına tekabül etmektedir. İnsanın çeşitli veçhelerden geçen psikolojik yolculuğu, bilincin kuşatılması ve kurulması anlamında işlevseldir. Bu nedenle mitler ile hikâyeler arasında çok derin farklar bulunmaktadır; çünkü mitler, okuyucudan bağımsız bir metin değildir, tersine, okuyucuyu doğrudan anlatının içerisinde özdeşleştirebileceği kurgularda yakalama uğraşındadır. Bu bakımdan mitlerin amacı ve işlevi, okuyucuyu, içinde bulunduğu kültürel dizgenin koordinatları ile buluşturma ve ona bulunduğu konumu göstererek kendilik bilincine erişmesini sağlamaktır. Dolayısıyla mit, bilinçdışı çözümlemesi gibi, topluluğun kendini kavrayabileceği bir yansıtıcı zemin olarak, topluluğun kendisine d1şarıdan bakarak kendini algılayabileceği düzlemdir. Bu, Lacan'cı bağlamda, Benlik adı verilen fenomenal göstergenin aslında bütünüyle öteki' nin bakışı tarafından kurulduğu ve anlamlandırıldığını gösterir. Nitekim Lacan için varoluşsal bilince ulaşma evreleri, varoluşun, dışarıdan gelen bakışımın nesnesi olmasına bağlıdır (Lacan 2013: 215-229, Homer 2013: 31-75). Bunu tersten okuduğumuzda şu sonuçla karşılaşırız: varoluşun, dışarıdan gelen bakışın nesnesi olduğu bilincine ulaşması, aynı zamanda kendisini bu dışarıdaki öğeden (Öteki) ayrımlaştırmış olduğu kavrayışına ulaşmasıdır. Mitin bütün işlevi, tam da bu bağlamda, psişik yaşamın dışsal bir anlatıda keşfedilmesi amacıyla kurgulanan bir anlatı sunmasıdır. Diğer bir deyişle, mitin işlevi, kendiliğin var olduğunun anlaşılabildiği sembolik bir dizgeyi kurgulayarak söylencenin içerisine çekilen bireyi, ki bu kişi söylencedeki kahramanla özdeşleştirilir, özneleştirmektir. Kişi, kendilik bilincine ulaştığı sembolik dizgeye söylencedeki görüngüler yoluyla katılarak özneleşir. Bunun açık anlamı, mitler insan varoluşunu dolaylı biçimde kurar; fakat mitik anlatı, geçmişte olup biten bir şeyin temsilinde değil, şimdiki zaman içinde bulunan mevcudiyet ile kökeni ve geleceği ilişkilendirebilme yetisinde açığa çıkar. Jung'un iddia ettiği gibi, mitler, kendiliği iki farklı zaman kipi arasında ilişkili biçimde konumlandırır 
(2009: 18); bir diğer deyişle tarih ve tarih-öncesi varoluşun mitik kurgusunda bir araya gelir.

Saydam, mitlerde dış dünyaya yansıtılan metaforik kurguların aslında içsel dünyanın unsurları olduğunu ifade eder (Saydam 2011: 10-11). Böylece anlatı ile bilinç ya da öznellik arasında özdeşlik bağı tesis edilmiş olur. Mit, bu yönüyle, insanı kültürel kılma pratiklerinin öyküsel dinamiklerini barındırarak, insanın çifte bölünüşünü (doğa-kültür) konu edinen bir deneyimi aktarır. Ancak bunun gerçekleşmesi, insanın çifte varoluşunun bölünmesindeki temel uğrak olan doğa-kültür karşıtlığının fenomenal düzlemde öznel biçimde deneyimlenmesine dayanır. Diğer bir deyişle, insan, bu karşılıklı bölünme sonucunda mevcut halinden kopuşuna dair bir bilinç geliştirmek zorundadır. Bu fenomenal deneyim, doğadan kopmak suretiyle kültürelleşme olgusuna kapı açarken, aynı zamanda doğa ve kültürün alanına dahil olan bilinç/öznellik arasına radikal bir mesafenin konmasını imler. Kültürün öznesi olan insan, bundan böyle doğadan ayrımlaşmış, onunla mesafelenmiş ve en önemlisi onu nesneleştirmek suretiyle kendi kültürel dizgesini hiyerarşik bir farklılık olarak deneyimleyebilecek olan faildir. Çünkü insan, bu düzlemde, kendisine başkasının bakışını (öteki) yöneltmek suretiyle varoluşunda mevcudiyetinden bir fazlalığa tekabül eden bilinci deneyimlemektedir. Bilincin ve öznelliğin koşulu, öyleyse, daima benlik ve dışarısı arasında belirli bir ayrımın kurulması ve bunun varoluşsal bir gereklilik olduğu varsayımına dayanmaktadır. $\mathrm{Bu}$, Jung’un arketipsel çözümlemesini andırmaktadır: Jung’a göre Benlik, tekil ve tam halde yalıtılmış biçimde olabilen bir varlık değildir; tersine o, daima varoluşunu tamamlayacak tinsel bir dışsallık arayışındadır (Jung 2005: 1819). Arketip, Ben’i dışarıdan tamamlayacak olan tinsel özdeşlik göstergesidir; Jung, çok iyi bilinen örneğinde arketip kavramını "anne” örneği üzerinden tartışır (2005: 22). Burada arketip, varoluşu tamamlamanın yanında onu anlamlandıran ve varoluşun gerekliliğini ve erekselliğini vurgulayan tinsel temsildir. Ancak arketip, zihinsel işlevden bağımsız değildir; öznenin bilincinde canlandırılması ve nesneye yansıtılması gerekir. Bu da, son kertede, bilincin bir yandan kendisini ayrımlaşmış bir varlık olarak deneyimlemesini, diğer taraftan da kendilik ile dışarısı arasında bilincin nesnesi yapılmaya müsait bir ilişki tasarlamasını gerekli kılmaktadır. 


\section{Türk Psiko-Mitolojisinde Varoluş, Örgütlenme ve Anlam}

Psiko-antropoloji literatürü ile bağlantılı kuramsal çabalar içerisinde yaygın olan görüş, her kültürün kendine özgü bir anlam evrenine sahip olduğu, fakat bunun sembolik inşasında kültürler-üstü bağlamda evrensel sayılabilecek kimi ortaklıklar içerdiği fikrine dayalıdır (Neumann 1989, Eliade 2001, Gürel ve Muter 2007, Cassirer 1997). Bunların başında Erginleşme, ,Ödipal Karmaşa ve Yeniden Doğuş temaları gelmektedir. Mitlerde konu edinilen hikaye, kahramanın bu süreçlerin içinden geçerek kendilik bilincine eriştiği evrelerden oluşur (Bonnefoy 2000: 788). Bunların her birinin ortak özelliği, mitsel anlatının içerisinde bilinç ve kültürel yapı arasındaki kopukluğu ve ayrımı sunması, daha doğrusu kahramanın yaşadığı travmayı konu edinmesidir. Travmanın nedeni, esas itibariyle hem mitik anlatının temel dinamiği, hem de mitin ana konusu olan kültürel dizge ile tanışma meselesidir. Çünkü mitin işlevi, bilinçlenmeyi bir tür erginleşme mitosu bağlamında tartışmak suretiyle, kültür (Sembolik Yasa) ve kendilik arasındaki ayrımı netleştirmek ve özneliği bu ayrım dahilinde inşa etmektir. İşte bu nedenle mitik anlatıda hikaye, daima, iki farklı ve karşıt tarihsel düzlemde cereyan eder. Kaostan düzen'e, tarih-öncesinden tarih'e, doğádan kültürr'e, dişil'den eril'e, vb. doğru gelişen ve dönüşen bir kavrayış ve buna dayalı oluşan topluluksal örgütlenme modeli, mitin bir dizge halinde sunmaya çalıştığı söylen bütününü meydana getirir.

Mitolojik kurgulamanın ana işlevine teorik arka plan sağlayan ve psikanaliz içerisindeki kimi travmatik ve nevrotik kurulumların temsilleri olan dizgelere Türk söylencesinde rastlamak mümkündür. Türk mitolojik düşüncesi ve Türk kültür tarihinin psikolojisi ile yakından ilgilenen yazarlar (Bayat 2006, Bayat 2007a, Bayat 2007b, Divitçioğlu 1987, Esin 2001, Hassan 2011, İnan 1976, İnan 1987, Ögel 1989, Ögel 1995, Roux 1994, Roux 2011), Türk kültürünün bilinçdışısı olarak sayılabilecek bazı bağlamlara dikkat çekmişlerdir. Bunların başında, Türkler'in çok tanrılı (Roux 2011: 11-18), Şamanist (Bayat 2006: 21-31) ve Anahanlı (Hassan 1954: 159) örgütlenme modeli içerisinde tarih sahnesinde belirdiğine ilişkin fikirler vardır. Türk mitolojisi, bu argümanlar göz önünde bulundurulduğunda, Şamanist inancın öngördüğü şekilde doğacıl bir varoluş tarzına göndermelerde bulunan anlatılar ihtiva eder (İnan 1986). Şamanizm, özünde, kutsal ve yeryüzü arasında birleşik ve ayrımlaşmamış bir ilişkiye dayanan tahayyül evrenini yansıtır. Diğer bir deyişle, Şaman inanç sistemi, varoluş ve varoluşun referans dizgesi olan kutsal arasında 
bütüncül bir bağ varsayar (Eliade 1999: 52-53). Böylece, varoluş, kendi farklılaşmışlığına dair bir bilinç geliştirmekten ziyade, kutsalllğın içinde yer alan bir öğe olarak algılanır.

Türk mitolojisinde Şaman inancı, Eliade'nin varsaydığı gibi, doğa ve doğa-üstü inanç sistemi arasındaki bütünleşik bağa dayanmaktadır. Bu mutlak birlik düşüncesi, tanrısallığın yeryüzüne yayılmış olduğunun ve kendisini ayrımlaşmış bir dışsallık olarak değil, yeryüzüne dağılmış ve saçılmış olarak gösterdiğinin bir göstergesi gibi anlaşılmaktadır. Nitekim, Şamanlar, doğal ve kutsal arasındaki bağın işlevcileridir; Kam adıyla anılmalarının nedeni, mutlak töz ile dünyasal bir bağ kurmalarıdır (İnan 1987: 393). Bu, Türkler'deki inanç sisteminin doğaya sinmiş bir tanrısallık düşüncesinde birleştiğini göstererek çok-tanrılı bir inanç sisteminin izlerini sunar. Örneğin Divitçioğlu, Türkler' in inanç sisteminin mitolojilerde yer aldığı şekliyle bilinen anlamıyla tek-tanrı inancı olamayacağını, zira tek-tanrı inancının özgül bir toplumsal örgütlenme aşamasının ürünü olduğunu (Divitçioğlu 1987: 63-4) söylerken; Hassan da kutsal olanın farklılaşmış bir düzleme ait olmayışının çok tanrılı bir inanç sistematiğinin temsili sayılması gerektiğini ifade eder (Hassan 2011: 49). Yine de Türk mitolojisinde kutsal ve inanç göstergesinde yer alan doğa imgesine bakıldığında tek-tanrı ya da çok-tanrı inanç dizgeleri tali kalmaktadır; çünkü Türkler’in mitik inançlarındaki özgünlük doğaya referansla oluşturulmuş kutsiyet bilincinin sosyal örgütlenme ile bireysel varoluşu kurma biçimidir. Durkheim’nn dinsel olan üzerine tasavvurunu andırırcasına, Türklerdeki Tanrı fikrinin, kendi manevi örgütlenmelerine yabancılaşmamış bir tanrısallı̆̆ı içerdiği söylenebilir. Nitekim Bayat, Şamanist inancın izleğini keşfedebileceğimiz bir inanç-örgütlenme modeli sunarken (2006), doğaya atfedilen kutsallığın Yaratıcı Anne ve onda görünür kılınan bir topluluk imgesinin dişil karakterine göndermede bulunur (2006: 127). Aynı şekilde Hassan için de Türkler'in ilksel örgütlenme biçimi, onların inanç sistemleriyle uyumlu şekilde, anahan$l \iota d ı r$ (2000: 71). Anahanlık, dişi’nin yaratıcılığına atfedilen kutsallığın aynı zamanda topluluğun manevi şahsında nedenselleşmesidir. Böylece anahanlı örgütlenme, Tanrı inancı ile topluluğun tinsel şahsiyetinin Yaratıcı Anne lafzında birleşmesi ve varoluş ve doğa arasındaki uyum yoluyla oluşan mutlak bütünlügün yansımasıdır. Burada varoluş, kutsal, inanç ve örgütlenme birbirine sıkı bir biçimde bağlanmış olduğu için, ayrımlaşmış bilinç tasavvurunun önüne set çekilmiştir. 
Anahanlı örgütlenme ve buna bağlı olarak bireysel varoluşun anlamlandırılması, doğa ve içinde yer alan tüm tekil öğelerin birbiriyle bütünlüklü uyumunu içerir. Kutsal ve varoluş arasındaki bağ, anahanlı örgütlenmenin doğayı ve kutsalı eş zamanlı biçimde kendinde görünür kıldığı dişil temsilde açığa çıkar. Türkler'in Şaman inancıyla pekiştirdikleri sosyokültürel yapıları göz önüne alındığında, bu dişil örgütlenmenin fonksiyonu daha net anlaşılabilir: kutsal ve doğanın dişil temsilde bütünlügü, bir yanıyla kutsalın çokluk biçiminde yeryüzüne yayılması ve kendisini her şeyde sunmakta olduğu fikrine yol açarken, öbür taraftan topluluğun kendi manevi bütünlügünün dişarıdan kavranabileceği dinsel bir dizgenin yokluğuna neden olur. Diğer bir deyişle, Şamanist inanç ile pekiştirilmiş anahanlı örgütlenme, yapısal olarak, topluluğun kendisini, bilinç düzeyinde ayrı bir nesne olarak ele almasını imkânsız hale getirmiş, böylece topluluğun kendini dinsel bir bakış yoluyla kavramasını engellemiştir. Bunun açık anlamı, Şamanist inanç ve anahanlı örgütlenme, topluluğun, kendisini ayrımlaşmış bir varlık olarak, diğer bir ifadeyle kendi varlığını fenomenal bir biçimde deneyimlemesini zorlaştırmıştır. Bu zorlukların bir göstergesi, Türk mitolojisinde kendini ăgaç mitosunda temsil eden manevi bütünlügün içerdiği yalıtılmış mekân düşüncesidir (Roux 2000: 27). Bu yalıtık mekân tasavvuru, her şeyden önce, varoluşun üretildiği anlam evreninin dışarısındaki yokluğa referansta bulunmaktadır. Diğer bir deyişle, Ağaç mitosunun önemi, kutsalın deneyimlenmesinde maddi varoluş ve kutsallık arasındaki ayrımı imkânsız kılmasındadır. Bu ayrımın yokluğu, daha doğrusu deneyiminin imkânsızlaştırılması, varoluşun kendisini ayrıksı bir varoluş olarak kavrayamayışının nedenidir.

Bir başka mitolojik unsur, yine Ağaç mitosu ile bağlantılı olarak, Er Sogotoh Destanı adıyla bilinen ve konusu yaradılıs olan bir söylencedir. Bu söylencede, arkaik mitosların bir örneği olarak ilk İnsan (Adem) tasavvuru sunulmuştur. Ancak bu yaradılış efsanesinde önemli olan unsur, ilk İnsan adıyla anılanın yaratıcı veya üretici bir fail düzeyinde sunulmamış olmasıdır. Diğer efsanelere bakıldığında, söylenin asıl konusu olan kahraman ve onun eylemlerinin bu efsanede yer almadığı görülür. Zira bu fail üzerinden anlatıya konu olan mevzu,

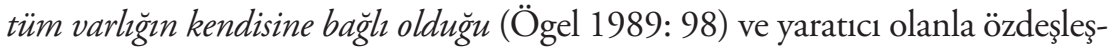
miş Ağaç mitosudur. Burada yalnızca Ağacın yaradılış olgusundaki önemine dikkat çekilmemektedir; mitosta yer alan ve fail olarak konumlandırılan aktörlerin bu Ağaç imgesi karşısında herhangi bir eylem dizgesiyle buluşturulmamış olmaları, bir başka deyişle özne-olamayışları bu söylenin ana konusunu oluş- 
turur. Ağaç-Ana imgesi üzerinden geliştirilen bu mitolojik kültür, bir taraftan varoluşun kendinde soğrulduğu kutsallığın dışarıda kalmaksızın varlı̆̆ı içinde erittiği bir sosyokültürel yapıyı imlerken, diğer taraftan da kadının animist düzeyde yaratıcı doğa ile benzeştirilerek kutsalın temsiline dönüştürüldüğü bir deneyimi işaretler. Anahanlı örgütlenmenin psişik boyutu diyebileceğimiz ve kendisini mitolojik bir örüntüde gösteren bu olgusal bağlam, yaradılışı yalnızca zamansal bir eksende konumlandırmaz. Çünkü Ağaç mitosunun hem mekânda (topluluk-toprak) hem de kutsal-kültürel bir göstergede (dişil-ana) sunumu, topluluğun hem varoluş, hem beslenme, hem korunma ve hem de tapınma ihtiyacını karşılayan bir kapsayıcı yalıtım düzlemi olarak kapalı bir Ağaç imgesini gösterir. Ağaç imgesinin böylesi kapalı ve yalıtık bir varoluş düzeyini işaretlemesi, varoluşun bütünüyle kuşatıldığı ve varoluşsal düzeyde ayrımların, sınırların ve farkların fenomenal bir deneyime tabi tutulamadığ bir yaşamsal dizgeyi gösterir. Bu yaşamsal dizge, yalıtımın sonsuzlaştırılmasından ötürü öznelliği büsbütün gerileterek, varoluşun fenomenal deneyimini sonsuz bir döngüye hapseder.

\section{Deli Dumrul Mitosu ve Türk-İslam Öznelliğinin Travmatik Deneyimi}

Türk mitolojisinde Şamanist inanç ile pekiştirilmiş anahanlı örgütlenmenin, varoluşun fenomenal bilinç düzeyinde kavranmasına engel olması ve buna dayalı olarak varoluşun özne olabilmesindeki kritik eşiğin atlatılamayışı, Deli Dumrul efsanesinde bir travma olarak gösterilir:

Deli Dumrul Boyu, bireysel düzlemde, varoluşunu zamanın maddenin sınırlayıcılı̆̆ının belirlediği her ölümlünün yaşaması kaçınılmaz, erekbilimsel bakıldığında 'gerekli' bir sarsıntının öyküsüdür. Bireyin dünyaya, öznel gerçekliğin diş gerçekliğe, bireysel erkin evrensel düzene çarptı̆̆ı; yeni bir iç-dış örgütlenme ve ilişki düzenlemesi gereksiniminin ortaya çıktığı bir karşılaşmadır. (Saydam 2011: 12)

Saydam’a göre, Deli Dumrul mitosunda anlatılan konu, bir karşılaşma anında deneyimlenen travmanın öznelliği inşa edici pozisyonudur. Bu karşılaşmanın travmaya neden olmasının sebebi, Türklerin animist-Şamanist varoluşları içerisinde deneyimledikleri doğa-kutsal birliğinin, ayrımlaşmış bir varlık olarak kendilik bilincine imkân tanımaması; ancak karşılaşma anında mevcut varoluşlarına indirgedikleri anlamın eksiltilmiş ya da yetersizleştirilmiş olmasıdır. Birazdan değineceğimiz üzere, Deli Dumrul mitosunda konu edilen şey, 
ölümle tanışma anında deneyimlenen bir yabancılaşmadır; varoluşun kutsal olan iç içe oluşu, ölüm gibi radikal bir dışsallığı tahayyülden ötede konumlandırmakta iken, ölümün bu evrenin içerisine sızarak görünür kılınması mevcut varoluşsal anlam dizgelerini tartışmalı kılmıştır.

Bunların başında, doğa (yeryüzü) ve kutsal arasındaki bütünlüğün bir temsili olan varoluşun sonsuzluğu yanılsamasının sona ermesi gelir. Yukarıda değindiğimiz üzere, Türk mitolojisinin hakim öğeleri Şamanist inancın öngördüğü gibi, varoluşun maddi ve tinsel öğelerinin bir arada dolayımlanmasını içerir; dolayısıyla varoluşa bir sonsuzluk ve sınırsızlık ufku bahşedilir. Hem Ağaç imgesinin imlediği yalıtılmış mekân içerisinde deneyimlenen kutsal-doğa bütünlüğünde, hem de Şaman inancının işaretlediği üzere topyekun yeryüzünün tinselleştirilmeye müsait hale getirilişinde, karşımıza çıkan olgu, ezeli ve ebedi bir bütünleşmişlik tahayyülü olmuştur. Varoluşun dişarıdan bakışa açık hale getirilmeyerek doğaya ve mekâna sindirilmesi, varoluşun ayrımlaşmış bir varlık olarak kavranmasını engellediği gibi, sonluluk düşüncesini zihinden çıkartarak varoluşun kaderini doğanın varlığından bağımsız kılmayan bir tahayyülü üretmiştir. Yeryüzünden ayrımlaşmamış olma hali, bu nedenle, sonsuzluk yanılsamasını hem varoluşsal düzeyde, hem de varoluşun anlamlı kılındığı sembolik-kültürel evrende türetmiştir.

Deli Dumrul mitosu, kısaca bu tahayyüllerin imlediği bir yanılsamayı görünür kılan ve varoluşun anlamlı kılınması adına mevcut sembolik kodların uzağına taşmayı gerektiren bir müdahaleyi anlatır. Bu mitosun travmatik olarak deneyimlenmesinin bilişsel nedeni, basitçe, failin yaşadığı öznellik dönüşümünde deneyimlediği kopuş ve dâhil oluş pratikleridir. Çünkü Deli Dumrul mitosu, bir taraftan İslami kültürel kodla tanışma ve ona dâhil olma anını konu alırken, diğer taraftan bu dâhil olma olgusunu mevcut kültürel dizgeden kopuş ile koşullandırarak sunmasıdır. Ölümü ve ölümlülüğü varoluştan yabancılaştıran Türk arkaik mitolojisi, ölümle karşılaşma anında failin kendisinden kopuşu yoluyla geride bırakılmaya çalışılan arkaik bir öğe olarak resmedilmektedir. Ancak bu geri bırakma davranışı hiç de kolay gerçekleşmez; çünkü geride bırakılmaya çalışılan arkaik kültürel anlam rejimi, dönüştürülerek bu yeni evrene dâhil olur. Böylece Türk-İslam öznelliği adı verilen kültürel faillik göstergesi, bu iki kültürel dizgenin failin bilinçdışı ve bilinç kategorileri arasındaki çatışma aracılığ 1 ile üretilen bir travmatik varoluşa neden olur. 


\section{Deli Dumrul'un Psiko-Mitolojik Çözümlemesi}

Deli Dumrul efsanesinde yer alan Duha Koca Oğlu Deli Dumrul başlıklı anlatı, Dumrul adlı babayiğidin kurumuş bir çayın üzerine köprü inşa ettirmesi ve herkesi bu köprüden geçirmeye zorlamasını konu edinir. Fakat anlatıyı önemli kılan husus, daha doğrusu anlatının psiko-mitolojik bir sorunsallaştırma nesnesi olmasının nedeni, Dumrul'un kurumuş çay üzerine yüklediği simgesel anlam olan sonsuz varoluş yanılsamasını başkalarının kabulü üzerinden idrak etme zorunluluğunu kavramasıdır. Diğer bir deyişle, Dumrul, çayın kurumuş olduğunun ayırdında olmamak adına, kendini bu gerçeklikten kopartacak simgesel bir anlam evreni inşa etme arzusundadır. Bu simgesel anlam evreni, çayın halen akmakta olduğunu, dolayısıyla herhangi bir olağanüstülüğün olmadığını Dumrul'a göstermekle işlevsel kılınmıştır. Burada farkında olmamız gereken şey, çay'ın simgesel değeri ve işlevinin Türk mitolojisindeki konumudur. Çünkü çay, hayatın kaynağı olan su’yun, dolayısıyla Türk mitolojisinde yaratıcı anne ile özdeşleşmiş olan Ak İne'nin temsilidir (Bayat 2007b: 248). Çayın kurumuş olmasına rağmen Dumrul'un bunu kabul etmeyişinin simgesel anlamı, o halde, yaradılış ve var ediş ile özdeş algıladığı dişil anlamın kapsayıcı ve kuşatıcı işlevinin halen geçerli olduğunu düşünmek isteyişidir. Diğer bir deyişle çayın kurumuş olmasına rağmen Dumrul'un anlam dünyasında akıyor oluşu, Dumrul'un bu ilksel varoluş evreninden kopmak istemeyişinin bir göstergesidir.

Dumrul'un kopmak istemediği evren, dişil olana bağlılığının üretilip muhafaza edildiği ve gerçeğin dünyasından bütünüyle yalıtık biçimde var olduğu yanılsamasını geliştirdiği ilksel anlam dünyasıdır, diğer bir deyişle anahanlı örgütlenmenin bilinçdışısal temeli olan Yaratıcı ve Koruyucu Anne imgesidir. Çay ile kurulan bağın sembolik işlevi, anne sütü yoluyla kurulan ve halen anneye aitliğin göstergesi olan nesne birliğinin tesisidir. Neumann, anneden kopuşa rağmen bu kopuşun geriye itildiği yanılsamalı anlamın anne sütünün simgesel kılındığı nesneleştirme ilişkisinde oluştuğunu ifade eder (1963: 1824). Anne sütü, çocuğun içinde bulunduğu fiziksel dünyaya tam anlamıyla dâhil olamadığının ve çocuğun halen anneye ait olduğunun bir göstergesidir. Anne sütü ile kurulan nesne ilişkisi, maddeye yüklenmiş simgesel anlam yoluyla psikolojik tatmin sağlayan (Kohut 1998) bir aidiyet bağını üretir. Bu aidiyetin temelinde yatan şey, çocuğun ilksel gereksinmelerinin bütünüyle anne tarafından sağlanmış olduğuna ilişkin bilinçdışısal izleğin doğum son- 
rasında da devam etmesidir. Daha doğrusu çocuk, anne tarafından tamamen doyurulduğu o ilksel evrenin devam edeceği inancına takılı kaldığı için, anne karnındaki doyum sürecinin doğum sonrasına da sarkacağı inancını besler. Winnicot, çocuğun bu gereksinimler ve tatmin arasında kurduğu bilinçdışısal ilişkiyi imgesel yanılsamasının temeli olarak görür (1998: 28). Çünkü çocuk için anne, kendi gereksinmelerinin tek ve mutlak sağlayıcısı olduğundan, anneden dışarısına ihtiyaç duymayan çocuk, böylece annenin dışarısında bir gerçeklik ya da kutsallık inancına sahip değildir. Ayrıca, çocuk için "anneden ötesi” olmadığı için ve dahası o, kendisini anneden ayrıksı bir biçimde kavramadığı için, çocuğun ayrımlaşmış bir kendilik bilincine sahip olmadığ düşüncesine ulaşabiliriz. Nitekim çocuk, gereksinmeleri ile anneden sağladığı tatmin arasında mutlak ve sarsılmaz bir bağ tesis ettiği için, kendisini annenin dişında kavramaz.

Yeniden anlatıya döndüğümüze, çayın işaret ettiği simgesel anlamı daha rahat çözümleyebilir ve Dumrul'un bilincindeki kopuşu daha açık görebiliriz. Çayın kuruması, Dumrul'un dişil olan ile özdeşleştirdiği anlam dünyasının istikrarsız hale gelişini göstermiş, böylece Dumrul'u travmatik bir hale sokmuştur. Kendi imgesel birliğini tahayyül etme imkânı olan Anne imgesini muhafaza etme arzusuna bağlı kalarak, kuruyan çayın üzerine köprü inşa etmiş, böylece kendi imgesel birliğini yeniden kavrama arayışına gitmiştir. Tam bu kavrayış çabası esnasında, köprüye yaklaşan bir oba içerisinde bir delikanlı vefat eder ve Dumrul, kendiliğin çözülmesi sürecinde Azrail'e kafa tutmak suretiyle Benliğini kavramaya ve kurmaya çalışacaktır. Bu andan itibaren Dumrul lafzında bir “erginleşme çabası" süreci başlayacak, bunun kolektif-kültürel ürünü olarak ise Türk-İslam öznelliğinin kurulum dizgeleri karşımıza çıkacaktır.

\section{Ölüm ile Karşılaşma, Anahanlı Örgütlenmenin Sarsılması ve Bilinç- Beden Ayrımının İlksel Ortaya Çıkısı}

Dumrul'un köprüye gelen oba'daki delikanlının ölümü karşısında Azrail'e meydan okuyuşu, bu mitosun en ilgi çekici yanlarından bir tanesidir. Burada, bir taraftan Dumrul'un anahanlı anlam dizgesinin sarsılma anında içine düştüğü boşluktan çıkma istenciyle açığa çıkan bir kendilik arayışının nüveleri görünürken, diğer taraftan bir dizi psiko-mitolojik öğenin anlatıda yer ettiği fark edilmektedir. Tekrar etmek pahasına, mitolojik çözümlemenin tıpkı bir rüya yorumlayışı gibi, hiçbir detayı atlamaksızın bir çözümleme girişimini gerektirdiği düşüncesinden hareketle, Azrail ile karşılaşma olgusunda (Ögel 
1995: 71-73) sembolize edilen olayın, basitçe, Dumrul'un bilinçdışı korkusu olan ölüm fenomeni olduğu fark edilecektir (Tura 2014: 89). Bilindiği gibi, ölüm ve ölümlülük temaları, Türk mitolojisinin genel bağlamı düşünüldüğünde, kolektif bilinçaltından dışarıya atılmış ve varoluşun Şamanist-anahanlı bağlamından kovulmuş öğelerdir (Ögel 1989: 104-105). Çünkü ölüm, varoluşun sonluluğunu imleyen bir gösterge olarak, varoluş ve içine konumlandığ1 kültürel evren arasındaki ayrımı işaretler. Oysa Türk mitolojisindeki anahanlı ve Şamanist kurgular göz önünde bulundurulduğunda, varoluşun özü gereği doğa ile bütünlüklü bir bağ deneyimlediği fark edilmektedir. Bu bütüncül bağın işlevi, varoluşu tıpkı anne karnındaymış gibi bir yanılsama evreni içerisinde doğa ile birleştirerek bilinçten soyutlamaktır. Bilinçten soyutlanmak, kendiliğin ayrımlaşmış bir kategori olarak kavranmadığı ve varoluşun doğaya sindiği mutlak özdeşlik durumunu ifade etmektedir.

Öyleyse Dumrul'un Azrail lafzında ölümle karşılaşmasının travmatik bir içeriği olduğu söylenebilir. Zira Dumrul, önce Azrail'e tıpkı ona denkmiş gibi yaklaşıp meydan okur:

Savaşayım, çekişeyim, uğraşayım, yahşı yiğidin canını kurtarayım. Bir daha yahşı yiğidin canını almasın. (Saydam 2011: 173)

Dumrul'un burada Azrail nezdinde ölüme meydan okuyor gibi görünmesinin nedeni, başta ifade ettiğimiz inanç sistematiği çerçevesinde Azrail' in temsil edildiği ruhsal mevcudiyetin dışarıda bırakılmış olmasıdır. Bu nedenle, Dumrul'un meydan okuyuşu, kendisi ile ölümün temsil edildiği Azrail arasındaki mesafeyi belirtmek içindir. Başka bir ifadeyle, Dumrul, meydan okuyuş vasıtasıyla Azrail ile aynı sembolik ortaklığı paylaşmıyor oluşunu ifade etmek istiyor gibidir.

Yine de bu ifadede Dumrul'un bilinçaltında Azrail'e, dolayısıyla ölüme dair eksik bir bilgi olduğu görülmektedir. Dumrul, Azrail'i savaşılabilecek veya kendisine karşı koyulabilecek bir hasım gibi görmektedir. Bunun nedeni, Dumrul'un içinde yetiştirildiği anahanl-Şamanist örgütlenmenin varoluşa dışsal bir öğenin bulunmadığı, var olan her şeyin bu kültürel evren içerisinde birbiriyle denk kabul edildiği bir anlam dünyası öngörmesidir. Dumrul'un ölüme meydan okumasının nedeni, ölümün de tıpkı kendisinin olduğu gibi anahanlılığa ait bir şeymiş gibi olduğunu sanmasıdır. Ona bu sanrıyı veren, elbette çayın sonsuz akışı ya da onun gerçeklik yanılsamasıdır. 
Nitekim anlatı, hemen ilerleyen satırlarda, Dumrul'un yeni bir farkındalığa meylettiğini gösterir. Dumrul, Azrail'e meydan okunamayacağını anlamış, böylece kendi varoluşu ve onu anlamlandıran ve sınırlarını belirleyen kültürel koordinatların hududuna erişmiştir:

Bre ne heybetli kocasin!

Kapıcılar seni görmedi,

Çavuşlar seni duymadi,

Benim görür gözlerim görmez oldu,

Tutar benim ellerim tutmaz oldu... (Saydam 2011: 173)

Burada anlatılmak istenen, Dumrul'un varoluşsal bir eksiklik hissi geliştirmesi, bunun nedeninin de ölümün karşısında varoluşun acziyetini travmatik biçimde deneyimlemekte olmasıdır. Ölüm, yalnızca Dumrul'un kültürel-sembolik koordinatlarını sarsıntıya uğratmaz, aynı zamanda ölümün karşısındaki acziyeti yoluyla kendi varoluşunun yaşamın radikal bağlamları karşısındaki dışsallığını idrak etmiş olur. Diğer bir deyişle ölüm, Dumrul'a, kendisinin ayrımlaşmış bir varlık olduğunu, ona, ölüm karşısındaki çıplaklığ 1 ile tanıtlayan şeydir. Burası oldukça kritiktir; zira Dumrul, ölüm karşısında sığınabileceği sembolik dizgeyi kaybetmiş olduğu için, ölüm karşısında savunmasızdır. Bu savunmasız oluşu, Azrail ile yenişemeyeceğini anlamasından çıkarsamak mümkündür:

...görür gözlerim görmez oldu, tutar benim ellerim tutmaz oldu.

Buradaki ifadeyi, Saydam, psikanalizdeki Ödipal karmaşada vurgulanan hadım edilme korkusu üzerinden çözümlemeye çalışır (2011: 173). Ellerin tutmaz, gözlerin görmez oluşu, bedensel aktivitelerin imkânsız kılınması yoluyla yeterlilikten uzak bırakılma olgusunu çağrışıırır. Ben, Saydam'dan farklı olarak, buradaki ifadenin daha derinlerde yatan bir kavrayışın deneyimlendiği düzlem olarak okunması gerektiğini ileri sürmek istiyorum. "Gözlerin görmez, ellerin tutmaz oluşu”, kendinde kavramaya başladığı bir yanılsama bilincinin izdüşümü olarak düşünülebilir. Dumrul'un, ölüm karşısında takındığı çelişkili tavrın kökeninde yatan şey, varoluşunun ölüm ile çekişebileceği yanılsaması karşısında geri adım atması, bunun sonucunda da ölüm ile çekişmesine müsaade eden imkânları (gözler, eller) kendisinden uzaklaştırması, daha doğrusu kaybetmesidir. İşte bu nokta, Dumrul'un giderek saf bilinç düzlemine erişe- 
rek ölümü tanıdığının göstergesidir. Çünkü her aşamada kendi varoluşunu anlamlandıran bir dizgeyi geride bırakan Dumrul, nihayetinde ölümün karşısında elleri ve gözleri olmaksızın durmakta ve ölümün kendisi için ne ifade ettiğini bu bedensel çıplaklık ve bilinç düzeyindeki doygunluk haliyle deneyimlemektedir.

Ölümün karşısında önce sembolik düzeyde konum alan ve bu konumdan hareketle ölüm ile çekişeceğini uman Dumrul, ardından Azrail ile yenişemeyeceğini anlar ve kendi varoluşu ile bu varoluşu anlamlandıran sembolik-kültürel dizgeye yabancılaşır. İşte bu andan itibaren Dumrul, ölümün karşısında varoluşundan sıyrılmış bir şekilde adeta çıplak haldedir ve saf bilinç düzeyinde ölümün karşısında durmaktadır. Bu konumlanmada fark etmemiz gereken şey, Dumrul'un saf bilinçli hali ile kendine yabancılaşmış oluşunun, yeni baştan doldurulacak ve tabii anlamlandırılacak bir boşluğa tekabül ediyor olmasıdır. Diğer bir deyişle Dumrul'un ölüm karşısında giderek varoluşsal dizgelerinden koparak saf ve bedensiz bir bilinç düzeyinde kalması, bu bilincin yeni baştan bedenleştirilmeye başlanacağı bir anlam dizgesinin gelmekte olduğunun habercisidir. Bu yeni anlam dizgesi, saf bilinci yeni baştan bedenleştirerek onu ayrımlaşmış bir Özne olarak kuracak olan İslamiyet ile tanışmadır.

\section{Tanrı'nın İdraki Yoluyla Eril Bilincin Yaratımı}

Azrail ile karşılaşmanın, varoluşa iliştirilmiş olan sembolik dizgenin (anahanlılık) anlam rejiminde yaratılan bir istikrarsızlığın deneyimi olduğunu yukarıda ifade ettik. Dumrul önce Azrail'e meydan okuma lafzında ölümlülüğü reddetmiş, fakat ardından ölümlülükten kurtulamamanın vermiş olduğu travmatik kabulün zorlamasıyla Tanrısal Yasa ile dolaylı bir buluşma gerçekleştirmiştir. Bu, Dumrul'un mevcut sembolik dizgeden koparak, kendiliği varoluşun dışarısında deneyimleyeceği bir uzaklığa yerleştireceği anlamına gelir. Zira hikâyenin geride kalan kısmında Tanrısal Yasa karşısında acziyetin kabulü ve Tanrı’ya sığınma olarak gerçekleşen edimler karşımıza çıkmaktadır (Özdarıcı 2011: 376-378).

Dumrul'un Tanrı'ya yakarışı, hikâyenin geri kalan kısmının ana konusudur ve burada söz konusu olan şey, ölüme meydan okuyan kahramanın bir anda ölümlülüğünü fark etmesi karşısında kendi acziyetini, daha doğrusu ölümün karşısında hiçliğini fark etmiş olmasıdır. 
Kalktı, atına bindi, doğanını eline aldı, ardına (Azrail) düştü...Döndü, evine gelirken Azrail atının gözüne göründü. At ürktü. Deli Dumrul’u kaldırdı yere vurdu. Kara başı bunaldı, darda kaldı. Ak göğsünün üzerine Azrail basıp kondu (Ergin 2003: 77).

Dumrul, ölüme meydan okumak için peşi sıra giderken Azrail'in Dumrul'un atına görünmesi ve onu ürkütmesi önemli bir ayrıntıdır. Bilhassa Türk mitolojisinin arkaik sembollerinden biri olan at, bilindiği gibi, kahramanın ruhu ile özdeşleşmiş, daha doğrusu ondan ayırt edilmeyen bir parça olarak telakki edilir (Belek 2015: 113-117). Mitolojik yorumlamada hiçbir detayın atlanmaması ilkesinden hareket edersek, at sembolünün seçilme nedeninin, Dumrul'un varoluş öğeleri arasındaki parçalanma veya sarsılma olduğu söylenebilir. Yukarıda değindiğimiz gibi, Dumrul'un varoluşundaki travma aşaması, varoluşun anlamını edindiği sembolik dizgenin istikrarsızlaşması, daha doğrusu Dumrul'un varoluşunu artık kuşatıp bütünüyle tanımlayamamasıdır. $\mathrm{Bu}$ olgunun gösterimi olan atının ürkmesi olayı, bu nedenle önemli bir ayrıntıdır; zira mitolojide kahramanın varoluşu içerisindeki doğal uzantı olan at figürü, bu anlatıda varoluşsal öğeler arası kopuşun bir temsili olarak ele alınabilir.

Bre Azrail aman

Tanrının birliğine yoktur güman

... Beylikten usanmadım yiğitliğe doymadım

Canımı alma Azrail medet (Ergin 2003: 77)

Dumrul, Azrail ile karşılaşır ve varoluşundaki eksiğin ayırdında olarak, onunla denk olamayacağını idrak eder. Ancak, bu ifadede iki önemli ayrıntı dikkat çeker: birincisi, Dumrul'un, “yiğitliğe doymadım” derken, kendi varoluşuna içkin gücünün sınırına ulaştığını kabul ve idrak ettiğini dile getirmek istemesi, ikincisi ise, Azrail'den medet umarak canının bağışlanmasını istemesidir. Kanımca bu yakarış, Dumrul'un mevcut varoluşundan koptuğunun bilincine vardığının ve varoluşundaki eksiğin farkına vardığının bir göstergesi olarak kavranabilir. Ben, buradaki farkındalığın bütünüyle anahanlı örgütlenmenin imlediği doğacıl-Şamanist tonlamanın reddi şeklinde ele alınabileceğini düşünüyorum. Nitekim Dumrul, ölüm ile karşılaşma anında varoluşunu anlamlandıran sembolik evrenin kuşatıcılığının eksikliğini, bizatihi ölümlülüğün içeriye sızmakta olduğu gerçeği sayesinde deneyimlemiştir. Diğer bir deyişle, Dumrul, o ana dek içinde yaşadığı yalıtık anahanlı dizge içerisinde dışarıda 
bıraktığı ölümlülüğü, bir anda karşısında bulmuş ve varoluşunun istikrarsızlı̆̆ına ilişkin görüyü o anda edinmiştir.

Dumrul'un Azrail ile karşılaşması, kendi ölümlülüğünün bilincine varması anlamında bir ara aşamadır. Bundan sonraki süreç, Azrail ile özdeşleştirdiği ölümlülüğün asli sahibi olan Tanrı ile karşılaşmadır:

Azrail der: Bre kavat bana ne yalvarıyorsun. Allah Taala'ya yalvar, benim de elimde ne var, ben de bir emir kuluyum dedi. Deli Dumrul der: Peki ya can veren can alan Allah Taala mıdır? Evet odur dedi. Döndü Azrail'e, peki ya sen ne eylemekli belasın, sen aradan çık, ben Allah Taala ile haberleşeyim dedi (Ergin 2003: 77-78).

Dumrul, böylece varoluşundaki eksiğin bilincine varmış olmanın sonucunda Allah ile buluşur. Buradaki sembolik anlatı çok önemlidir: Allah’a kavuşma, sonluluk görüsünün deneyimlenmesi yoluyla varoluştaki eksikliğin bilincine erişme anında gerçekleşir. Dolayısıyla Allah'ın Dumrul'a görünmesi asla zamansal bir mesele değil, tamamen bilinç ve idrak meselesidir. Dumrul'un anahanlı örgütlenme içerisinde deneyimlediği bütünlük yanılsaması, önce çayın kuruması gerçeği karşısında sınanmış, ardından ölümlülüğe meydan okuyuş esnasında varoluşunun uzantısı olan at'ının ürkmesi ile nihayete ulaşmıştır. Her iki olayda da Dumrul, ölümlülüğünün bilinci yoluyla kendiliğin eksik bağlamını deneyimleyerek, varoluşunun anahanlı dizge içerisinde yalıtılmış addedildiği sembolik düzleme yabancılaşmıştır.

Allah Azrail'e buyurdu ki, madem deli kavat benim birliğimi bildi, birliğime şükür kıldı, ya Azrail, Deli Dumrul, can yerine can bulsun, onun canı azat olsun der (Ergin 2003: 78).

Açıkça görülmektedir ki, Allah, Dumrul'un canını bağışlayacaktır, lakin Dumrul'dan bir can vermesini ister. Dumrul'un önce babasindan can istemesi, fakat babasının "benden kıymetli anan var" sözüyle (Ergin 2003: 79) anasının canını işaret etmesinin sembolik önemi, Dumrul'dan istenen şeyin açıkça anahanlılıktan kopma olduğu gerçeğidir. Allah, bu canı, yalnızca Dumrul'un canını bağışlamak için bir "kurban" olarak talep etmez; daha ziyade, Allah’ın isteği Dumrul'un yabancılaştı̆̆ varoluşuna geri dönüşü sonsuza dek kapatmak ve Dumrul'u Allah'ın mutlak Yasası'na ve Bir'liğine dâhil ve ait kılmaktır. Bilinçlenmenin bedeli, burada feda, yani kurban etmektir. 
Dumrul'un ana ve babasının canlarını vermemeleri karşılığında, Allah’ın hükmü değişmezdir: İslamiyet'in öngördüğü Yasa'ya dâhil olmanın şartı, açık biçimde, doğuş mitosuna ait özdeşlik nesnesinin yitimi olarak anahanlı evrenin yıkıma uğratılması ve buna karşılık kahramana "yeniden doğuş” yoluyla “erginleşme” olanağının sunulmasıdır (Eliade 2015). Doğuş, psikanalizdeki doğum travması öncesine tekabül eden süreçtir. Çocuk, bu travmayı aşmak için doğum öncesi anın deneyimini tekrarlamak adına, anne ile kurulan ilksel bağı belirli bir nesne yoluyla tekrar etmeye yönelerek anne sütü ile duygusal ve psişik bir bağ oluşturur. Bu bağın kurulduğu ilişkide çocuk, dış dünyadan yalıtılmış haldedir; diğer bir deyişle tüm varoluşu annenin kuşatıcılığı altında olduğundan, kültürel evren olan Baba’nın Yasası'yla henüz tanışmamıştır. Baba’nın Yasası, burada anne ile kurulan bağın sonrasında kahramanın artık kültürel bir fail olarak anneden uzaklaştığı, diğer bir deyişle ergin hale geldiği düzleme işaret eder. Çocuğun anne ile kurduğu yalıtılmış-yanılsamalı varoluşu, Baba’nın Yasası yoluyla kültürel olan tarafından soğrulur. Diğer bir ifadeyle çocuğun erginleşmesi, anne ile kurulan imgesel-yanılsamalı varoluşa yabancılaşma neticesinde Baba’nın Yasası'na dâhil olmaktır.

Deli Dumrul mitosunda anlatılan şey, basitçe, bu erginleşme sürecinin sonucunda anahanlı dizgeden ayrılarak babahanlı dizgeye geçişin travmatik deneyiminin yansıtılmasıdır. Roux, Türkler'in hem İslamiyet'i kabul etmiş olmalarında, hem de bu geçişin psişik temsili olarak Babahanlılığa geçme olgusunda, ölümlülüğün def edilişi olgusuna eğilmeyi önerir (Roux 1994: 212-214). Anahanlı dizgedeki çatlakta meydana gelen ölüm korkusunun, varoluşu yok oluşa doğru sevk ederken Baba’nın Yasası ile karşılaşma anında kahramanımız, Tanrı tarafından ölüme karşı mücadeleye soyundurulur. Bu mücadelede kahramana verilmek istenen mesaj, ölüm gerçeğini Allah’ın dolayımıyla kabul etmenin ölüm korkusunu atlatmasında temel uğrak olacağını söylemektir. Başka bir deyişle fail, yok oluş korkusunu, Baba’nın sembolik yasasına dâhil olarak ve bu yasa dizgesinde belirli bir “öznellik” konumuna oturarak sembolik biçimde def eder. Ölüm kaygısı artık ait olunan anlam dünyasının dışarısında değil, tersine tam merkezindedir ve faili özne konumuna oturtan da bu bilinçlenmedir.

Ben, kendisini anahanlılıktan babahanlılığa geçiş olgusunda gösteren bu bilinçlenme anının doğrudan eril bir bilinçlenme modeli olarak okunması gerektiğini öne sürüyorum. Türklerin Şamanist-anahanlı örgütlenmelerinin 
anlam dünyasındaki insan-doğa ilişkisinin bütüncül bağlamı, İslamiyet'e geçiş ile beraber, yerini insan ve doğa arasında mesafeli bir ilişkiye bırakmıştır. Şamanist inancın kutsal ve doğa arasında kurduğu doğal bağ, İslamiyet'in tek Tanrı inancının öngördüğ̈̈ örgütlenme ile akamete uğrar. Zira İslamiyet'in öngördüğ̈̈ sembolik adlandırmanın temelinde, toplumsal ve kültürel örgütlenme ilişkisi vardır (Berktay 2012: 19). Anahanlılığın doğa ve kutsal arasında gördüğü bütüncül bağ, bu anlam dünyası içerisinde yalıtılmış ve bu yönüyle doğadan ayrımlaşmamış bir "Ben” motifini esas almakta iken, İslamiyet ile beraber doğanın nesneleştirilerek insanın kullanımına ait kılındığı bir örgütlenme modeline geçilmiştir. Bu geçişin eril bir özneleşmeyi işaret etme nedeni, açıkça, varoluşun ayrımlaşmış - diğer bir deyişle erginleşmiş - olduğu gerçeğinin idraki ve tasdikidir. Unutmamak gerekir ki Dumrul, diğer her şeyden ayrımlaşmış olarak Allah'a temas edebilmiştir. Dumrul'un Anahanlı örgütlenmeden kopuşu, atının ürkmesi, kendi varlı̆̆ının selameti açısından ana ve babasından gerekirse kopartılabileceği gerçeği, vb. temalar düşünüldüğünde, Dumrul lafzında İslamiyet'e geçişin simgesel bağlamı, varoluşun içine düştüğü anlamsızlık ve istikrarsızlık sarmalından kurtulma olarak erginleşmenin ve bir bilinç olarak ayrımlaşmanın kurulumudur.

\section{Sonuç}

Psiko-mitolojik bir sorunsallaştırma ekseninde Türk-İslam öznelliğini Deli Dumrul adlı mitos üzerinden ele almaya çalıştığım bu makalede, Türklerin kendilik kavrayışlarındaki anlamlandırma rejimini ve bu anlam dünyasının karşılaştığı travmayı sembolik yorumlama dâhilinde kurgulamayı amaçladım. Deli Dumrul hikâyesi, Türklerin anahanlı bir anlam dizgesi içerisindeki travmatik deneyimlerini ve Türklerin İslamiyet’i kabul edişleri esnasında ne gibi duygusal süreçler deneyimlediklerine dair bir kavrayış geliştirmemize imkân tanıyan bir efsanedir.

Mitosların yalnızca kolektif bir hafızayı değil, fakat toplumsal bilinçdışını imledikleri hesaba katıldığında, Deli Dumrul hikâyesinde Türk-İslam öznelliğinin kurulumundaki süreçleri ve neden olduğu kopuşları, eklemlenmeleri ve kendilik kavrayışını çözümleyebilmekteyiz. Türkler, mitolojik yaşantılarında çok tanrılı olmasa da çoklu kutsal inancına sahiplerdi. Dolayısıyla Türk mitolojisi, evreni kuşatan ve insanı doğadan ayrımlaşmış 
kılan ve yine insanı sorumlu faile indirgeyen aşkın bir hakikat kavrayışı içermemekteydi. Türklerin tek tanrılı bir din olan İslamiyet'i kabulünün yaratmış olduğu en radikal dönüşüm, belki de hem epistemolojik düzeyde hem de ontolojik düzeyde doğadan ayrımlaşmış ve onu nesneleştiren bir bilincin ortaya çımış olmasıdır. Bu bilinç, ebedî dönüş mitosunu daima anacıl dizgeye yönelten Türk bilinçdışısal izleğin anne ile irtibatını kesmiştir. Doğa ile kurulan Şamanist inanç birlikteliğinin yerini, doğa ile mesafeli bir erillik ilişkisi almıştır.

Özetle, Deli Dumrul efsanesi yalnızca edebi bir kurguyu değil, aynı zamanda kolektif bilinçdışının izleğini sunması bakımından ve Türk-İslam öznelliğinin arkeolojisinin yapılması anlamında bizlere tarihsel ve politik bir hat sunmaktadır.

\section{Kaynaklar}

Bayat, Fuzuli (2006). Ana Hatlarryla Türk Şamanliğı. İstanbul: Ötüken Yay.

Bayat, Fuzuli (2007a). Türk Mitolojik Sistemi I Ontolojik ve Epistemolojik Bağlamda Türk Mitolojisi. İstanbul: Ötüken Yay.

Bayat, Fuzuli (2007b). Türk Mitolojik Sistemi II Kutsal Dişi-Mitolojik Ana-Umay Paradigmasinda İlkel Mitolojik Kategoriler-İyeler ve Demonoloji. İstanbul: Ötüken Yay.

Belek, Kayrat (2015). "Eski Türklerde At ve At Kültürü”. Gazi Türkiyat: 111-128. Berktay, Fatmagül (2012). Tek Tanrlı Dinler Karşısında Kadın Hıristiyanlıkta ve İslamiyette Kadının Statüsü Üzerine Karşzlaştırmalı Bir Yaklaşım. İstanbul: Metis Yay.

Bonnefoy, Yves (Yay. haz.) (2000). Antik Dünya ve Geleneksel Toplumlarda Dinler ve Mitolojiler Sözlüğü. Çev. Levent Yılmaz. Ankara: Dost Yay.

Campbell, Joseph (2006). İlkel Mitoloji/Tanrı'nın Maskeleri. Çev. Kudret Eminoğlu. Ankara: İmge Yay.

Cassirer, Ernst (1997). Devlet Efsanesi İnsan Üstüne Bir Deneme. Çev. Necla Arat. İstanbul: Say Yay.

Divitçioğlu, Sencer (1987). Kök Türkler Kut, Küç ve Ülüg. İstanbul: Ada Yay.

Durkheim, Emile (2011). Dini Hayatın İlkel Biçimleri. Çev. Fuat Aydın. Ankara: Eski Yeni Yay.

Duymaz, Ali (2008). "Türk Folklorunda Dış Ruh Tasarımı”. Bilig-Türk Dünyası Sosyal Bilimler Dergisi 45: 1-22.

Eliade, Mircea (1999). Şamanizm İlkel Esrime Teknikleri. Çev. Tuncay Birkan. An- 
kara: İmge Yay.

Eliade, Mircea (2001). Mitlerin Özellikleri. Çev. Sema Rifat. İstanbul: OM Yay.

Eliade, Mircea (2015). Doğus ve Yeniden Doğuş İnsan Kültürlerinde Erginlenmenin

Dini Anlamları. Çev. Fuat Aydın. İstanbul: Kabalcı Yay.

Ergin, Muzaffer (2003). Dede Korkut Kitabr. İstanbul: Hisar Yay.

Esin, Emel (2001). Türk Kozmolojisine Giriş. İstanbul: Kabalcı Yay.

Günay, Ünver ve Harun Güngör (2015). Başlangıçlarından Günümüze Türklerin Dini Tarihi. Ankara: Berikan Yay.

Gürel, Emet ve Canan Muter (2007). "Psikomitolojik Terimler: Psikoloji Literatüründe Mitolojinin Kullanılması". Sosyal Bilimler Dergisi 1: 537-569.

Hassan, Ümit (1984). "Evrim Teorisi ve Anahanlık Tartışmaları". Ankara Üniversitesi SBF Dergisi 39 (1): 157-166.

Hassan, Ümit (2011). Eski Türk Toplumu Üzerine İncelemeler. Ankara: Doğu Bat1 Yay.

Homer, Sean (2013). Lacan. Çev. Abdurrahman Aydın. Ankara: Phoenix Yay.

İnan, Abdulkadir (1976). Eski Türk Dini Tarihi. İstanbul: MEB Yay.

İnan, Abdulkadir (1986). Tarihte Ve Bugün Şamanizm Materyaller ve Araşttrmalar. Ankara: TTK Yay.

İnan, Abdulkadir (1987). Makaleler ve İncelemeler I. Ankara: TTK Yay.

Johnson, Robert (1992). Erkek Psikolojisini Anlamak. Çev. K. Kutlu. İstanbul: Gül Yay.

Jung, Carl Gustav (2005). Dört Arketip. Çev. Zehra Aksu Yılmazer. İstanbul: Metis Yay.

Jung, Carl Gustav (2009). Anılar, Düşler, Düşünceler. Çev. İris Kantemir. İstanbul: Can Yay.

Kohut, Heinz (1998). Kendiliğin Yeniden Yapılanması. Çev. Oğuz Cebeci. İstanbul: Metis Yay.

Lacan, Jacques (2013). Psikanalizin Dört Temel Kavramı Seminer 11. Kitap. Çev. Nilüfer Erdem. İstanbul: Metis Yay.

Leeming, David Adams (1990). The World of Myth. New York: Oxford University Press.

Neumann, Erich (1963). The Great Mother An Analyses of the Archetype. Çev. Ralph Manheim. New Jersey: Princeton University Press.

Neumann, Erich (1989). The Origins and History of Consciousness. London: Maresfield Library.

Niles, John (1999). Homo Narrans: The Poetics and Anthropology of Oral Literature. Philadelphia: University of Pennsylvania Press.

Noland, Richard W. (2010). "Psikotarih: Teori ve Pratik". Çev. Mustafa Alican. Tarih Okulu 6: 95-123.

Obeyesekere, Gananath (2011). Kültürün Işleyişi Psikanaliz ve Antropolojide Sembo- 
lik Dönüşüm. Çev. Jale Ergelen. İstanbul: Doruk Yay.

Ögel, Bahaeddin (1989). Türk Mitolojisi I. Ankara: TTK Yay.

Ögel, Bahaeddin (1995). Türk Mitolojisi II. Ankara: TTK Yay.

Özdarıcı, Öznur (2011). "Anlatı Tekniği Açısından 'Duha Koca Oğlu Deli Dumrul Destanı'nı Bir Çözümleme Denemesi”. Uluslararası Sosyal Araştırmalar Dergisi 4 (16): 371-380.

Rank, Otto (2016). Kahramanın Doğuş Miti. Çev. Gökçe Yavaş. İstanbul: Pinhan Yay.

Roux, Jean Paul (1994). Türklerin ve Moğolların Eski Dini. Çev. Aykut Kazancigil. İstanbul: İşaret Yay.

Roux, Jean Paul (2000). "Ağaç: Türklerde ve Moğollarda Hayat Ağacı ve Kozmik Eksen”. Der. L. Yılmaz. Antik Dünya ve Geleneksel Toplumlarda Dinler ve Mitolojiler Sözlüğ̈ I-II. Ankara: Dost Yay. 27-28.

Roux, Jean Paul (2011). Eski Türk Mitolojisi. Çev. Musa Yaşar Sağlam. Ankara: Bilgesu Yay.

Saydam, M. Bilgin (2011). Deli Dumrul'un Bilinci Türk-İlam Ruhu Üzerine Bir Kültür Psikolojisi Denemesi. İstanbul: Metis Yay.

Strauss, Claude Levi (2013). Mit ve Anlam. Çev. Gökhan Yavuz Demir. İstanbul: İthaki Yay.

Tura, Saffet Murat (2014). Şeyh ve Arzu. İstanbul: Metis Yay.

Voloşinov, Valentin Nikolayeviç (2016). Freudculuk Eleştirel Bir Taslak. Çev. Cem Soydemir. Ankara: Doğu Batı Yay.

Winnicot, Donald (1998). Oyun ve Gerçeklik. Çev. Tuncay Birkan. İstanbul: Metis Yay.

Zupancic, Alenka (2011). Neden Psikanaliz? Ü̧ Müdahale. Çev. Barış Engin Aksoy. İstanbul: Metis Yay. 


\title{
Psyco-Mythological Analysis of Turkish- Muslim Subjectivity in the Context of the Myth of Deli Dumrul*
}

\section{Efe Baştürk**}

\begin{abstract}
Any social structure does build a symbolic world in accordance with its collective organization. Myth is a narration designed about the establishment of the society and the ego of that symbolic world. The psycho-mythology is a kind of interpretation which argues the both evolution and effect of collective culture on transformation of the psyche of self. The myth of Deli Dumrul, based on Islamic transition of Turks, narrates a trauma of a hero living within a Shamanist religion when he just realized his mortality. The root of this trauma is the destabilization of the psychology before the normative sequence of Islam. The reason why that psychology experienced such a quake is because it had been established in a native and Shamanist organization to be alienated by Islamic normative order. The myth of Deli Dumrul could be handled as a problematic object of psycho-mythology as it includes the experiences in process of integration to subjectivity which Turks gained them with participation to Islamic order.
\end{abstract}

\section{Keywords}

Turkishness, maternality, Islamism, psycho-mythology, mythos, Deli Dumrul.

\footnotetext{
Date of Arrival: 23 December 2016 - Date of Acceptance: 25 April 2017 You can refer to this article as follows:

Baştürk, Efe (2019). "Psyco-Mythological Analysis of Turkish-Muslim Subjectivity in the Context of the Myth of Deli Dumrul". bilig - Journal of Social Sciences of the Turkic World 89: 29-54

" Assoc. Prof. Dr., Recep Tayyip Erdoğan University, Faculty of Economics and Administrative Sciences, Department of Political Sciences and Public Administration - Rize/Turkey ORCID ID: https://orcid.org/0000-0001-7117-0734 efe.basturk@erdogan.edu.tr
} 


\title{
Психо-мифологический анализ турко-мусульманского субъективизма в контексте мифа Дели Думруле*
}

\section{Эфе Баштюрк*}

\begin{abstract}
Аннотация
Любой социальный коллектив строит символичный мир в соответствии с его организацией. Миф же является повествованием об основании коллектива и о характере сотворенного мира. Психо-мифология, в свою очередь, это подход, который изучает становление индивидуального характера, в том числе и вследствие коллективного мифа. Миф о Дели (сумасшедшем) Думруле, основанный на переходе тюрков в ислам, рассказывает о травме главного героя, шаманиста, узнавшего о своей смертности. Причина травмы - дестабилизация психологии героя в связи со столкновением натуралистских взглядов тюрков с устоями ислама. Миф о Дели Думруле может быть рассмотрен как объект психо-мифологии, так как он включает опыт перехода и интеграции тюрками субъективизма ислама.
\end{abstract}

\section{Ключевые слова}

тюрки, ислам, психо-мифология, миф, Дели Думрул

\footnotetext{
* Поступило в редакцию: 23 декабря 2016 г. - Принято в номер: 25 апреля 2017 г. Ссылка на статью:

Baştürk, Efe (2019). "Deli Dumrul Mitosu Bağlamında Türk-İ̉lam Özneliğinin Psiko-Mitolojik Çözümlenmesi”. bilig - Журнал Гуманитарных Наук Тюркского Мира 89: 29-54

** Доц., д-р, Университет Реджепа Таййипа Эрдогана, факультет экономики и управления, Кафедра политологии и государственного управления - Ризе / Турция ORCID ID: https://orcid.org/0000-0001-7117-0734 efe.basturk@erdogan.edu.tr
} 